\title{
The phylogeny of Critical Zone Observatories, or how to better structure existing observation networks to match the whole system approach
}

\author{
Jérôme Gaillardet ${ }^{(1)}$, Isabelle Braud ${ }^{(2)}$, François Mercier(1) \\ Sylvie Galle ${ }^{(3)}$, Virginie Entringer ${ }^{(1)}$ \\ (1) IPGP, Université de Paris, Paris, France \\ (2) INRAE, RiverLy, Lyon, France \\ (3) IGE, CNRS-IRD-UGA, Grenoble, France
}




\section{Outline of the presentation}

1. Context and objectives: the Whole System Approach and existing observation networks

2. A visualization of observatory networks rationale: the OZCAR Tree

3. More details on the proposed visualization

4. How to go beyond a nice visualization tool?

5. Conclusions and perspectives

On each slide, click on the arrow

to come back to the presentation outline 


\section{Context of the Anthropocene}

- Human beings have become geological agents and are modifying their life environment

- There is a urgent need to preserve the habitability of the Earth so that human beings car sustain their needs in terms of water, soil, food resources

- Ecosystems, critical zones and socio-ecological systems observatories are critical elements to understand the interplaying processes and build the models that can "earthcast" the trajectory of the territories in the Anthropocene.

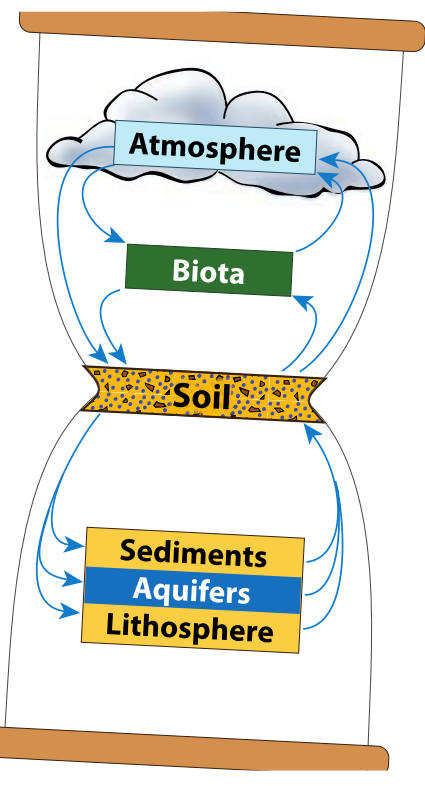

$=>$ These observatories must rely on a systemic, multicompartments approach: the Whole system Approach for In-situ \& Long-term environmental System research on Life supporting Systems (WAILS) 


\section{The WAILS approach}

- A multi-scale approach from local to regional scale

- A multi-disciplinary approach sampling the various compartments of the ecosystems, critical zone and socio-ecosystems

=> Need for dedicated observation networks

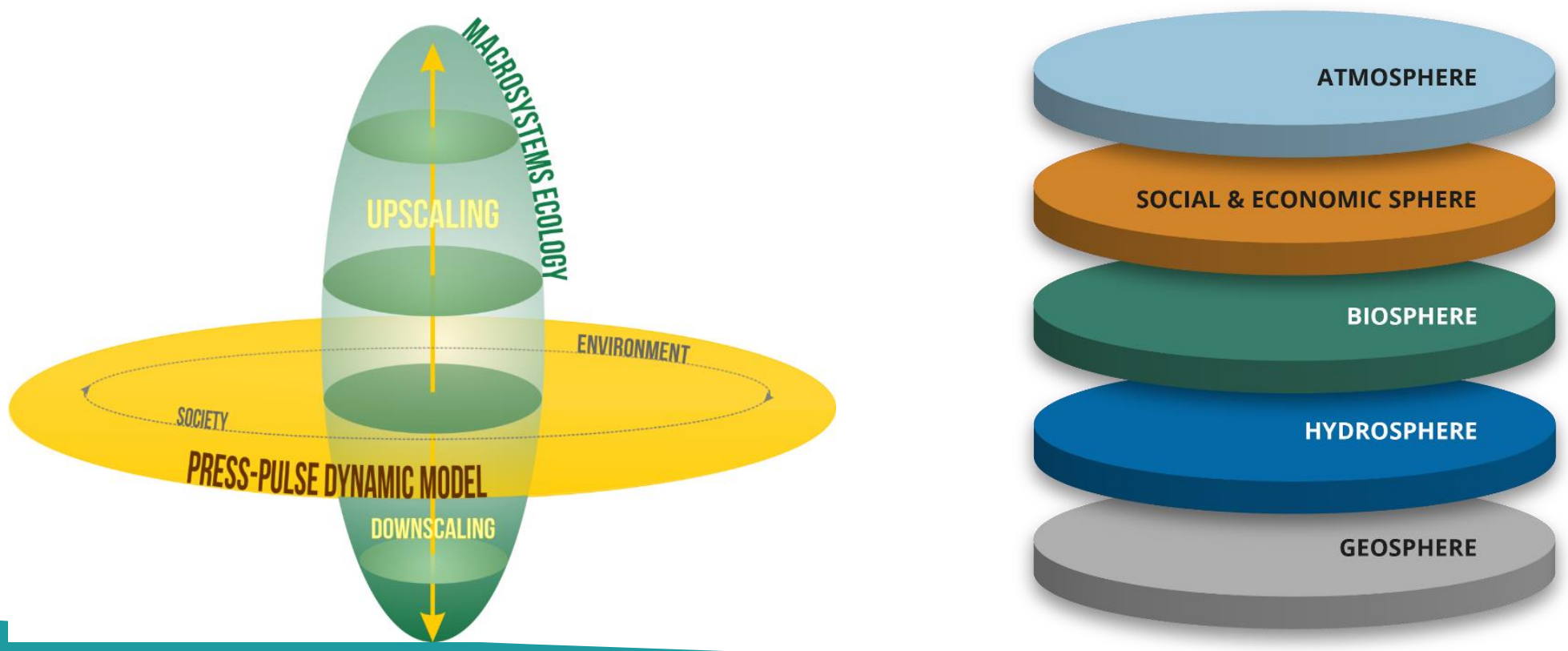




\section{How to set up the WAILS approach?}

Diversity and heterogeneity of the targeted system

$=>$ How to design the observation set up to fulfil the WAILS approach?
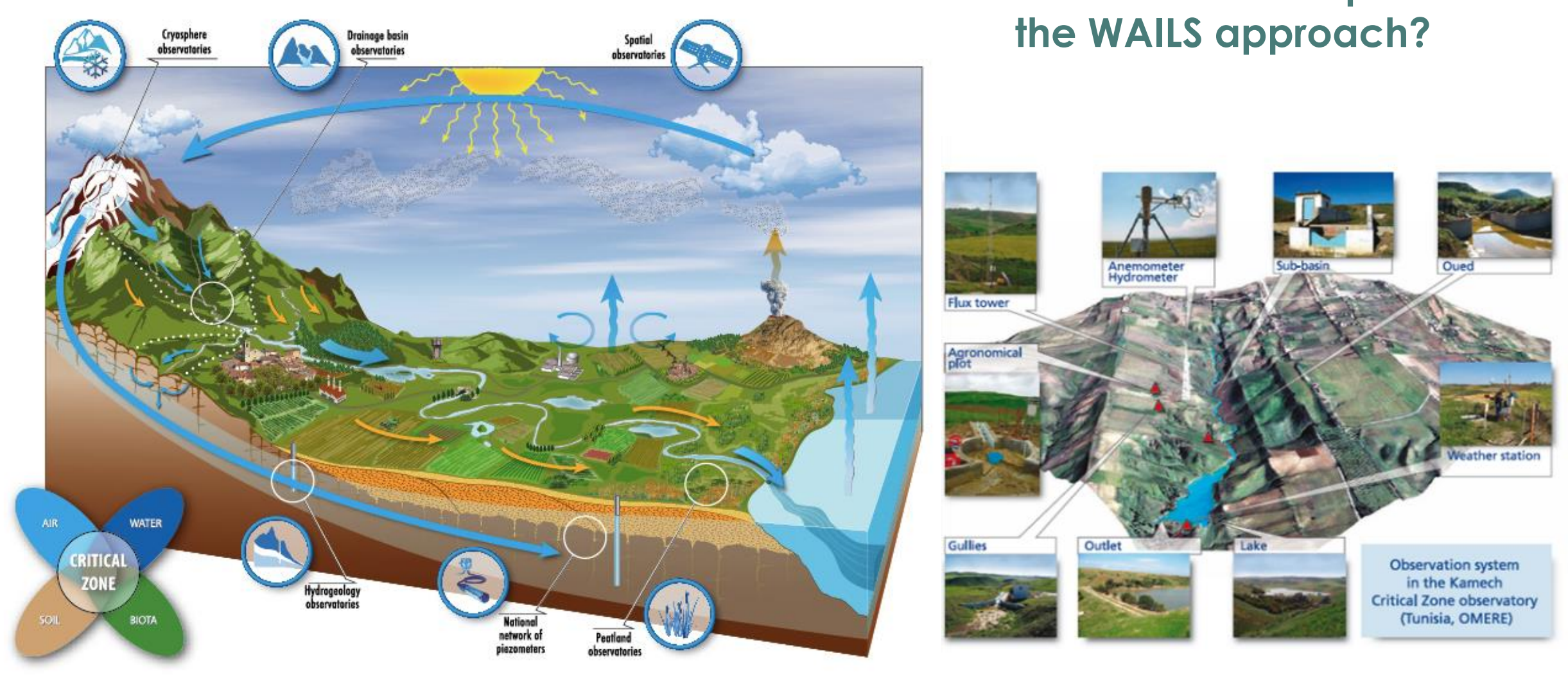
How fo set up the WAILS approach?

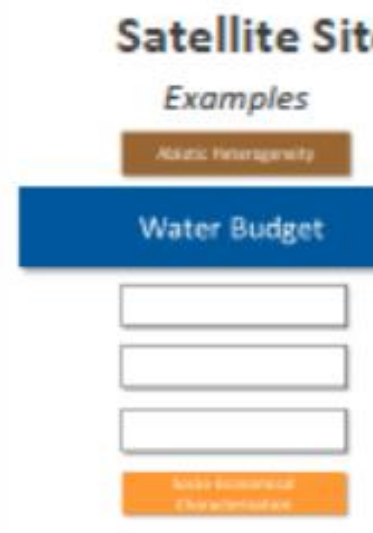

Regular Site

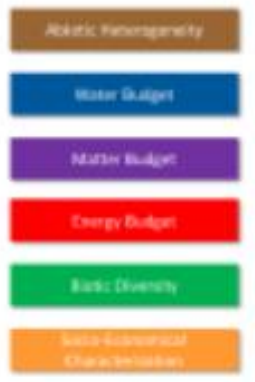

Focal Site

Examples

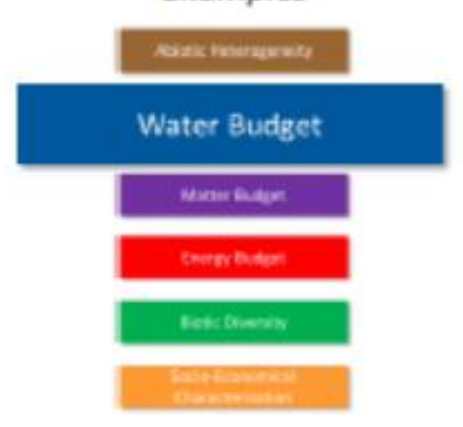

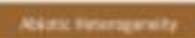
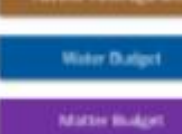

convers:

Miotic Oiversity

Biotic Oiversity

Sosio-Eronomice
Characterizatio

Platforms and NRI specific spatial assemblage
Platform
Master Site

Abiotic Heterogencity

Water Budget

Matter Budget

Energy Budget

Biotic Diversity

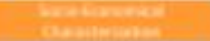

Example: a hierarchy of sites proposed in eLTER-RI

BG3.13 - 'Whole system approach for in-situ \& long-term environmental system research on life supporting systems (WAILS) 


\section{How to set up the WAILS approach?}

- A large number of existing observation networks that were historically independently built on specific research questions with a large heterogeneity in object of interest, measured variables, organization, funding etc...

$=>$ Need for diagnostic tools to identify where and how the WAILS could be deployed, how the hierarchy of sites could be defined

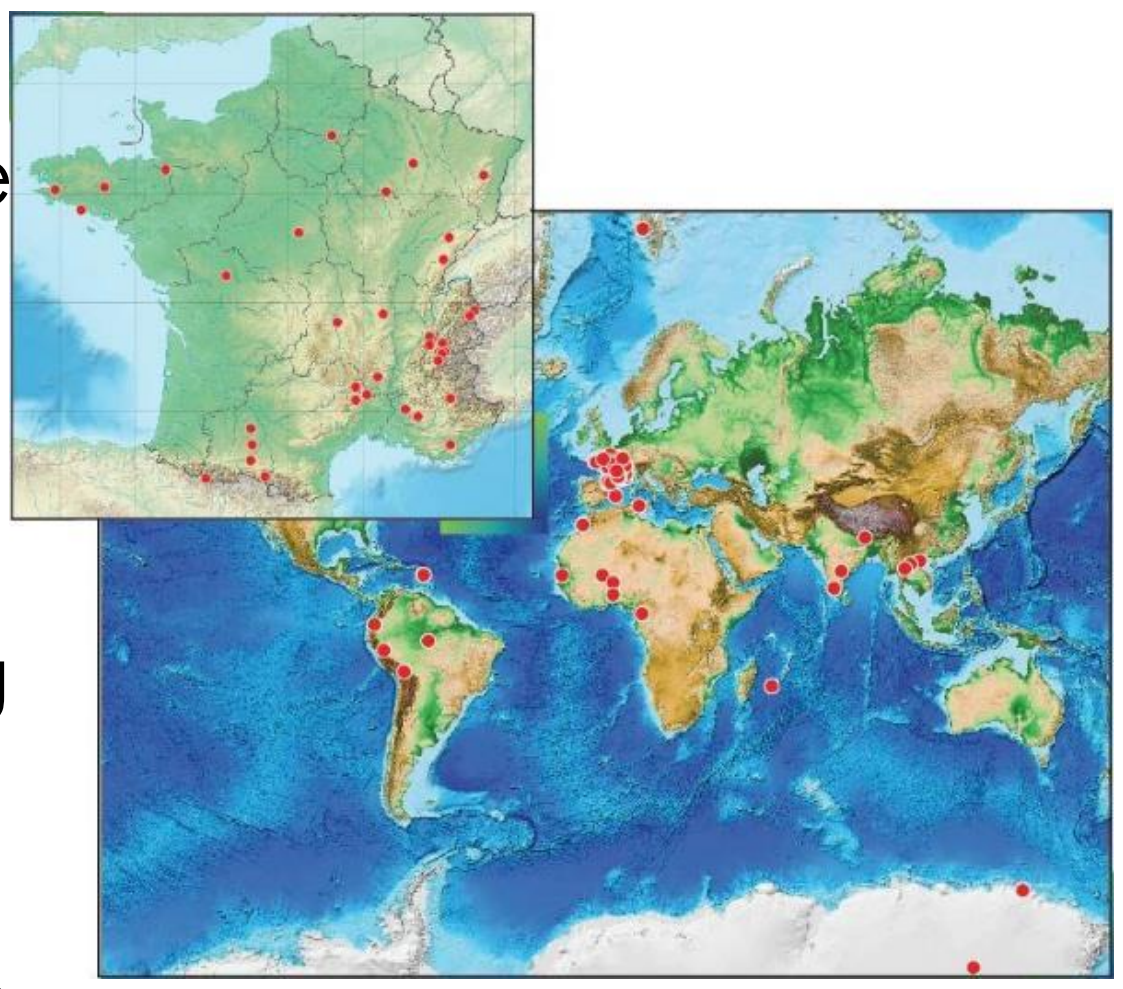

A typical example: the OZCAR RI observation network: about 60 historical observation sites with different objectives 


\section{A visualization ti the OZCAR Tree}

$=>$ An analogy with the phylogenetic tree to represent various aspects of the OZCAR RI observatory network that are detailed later

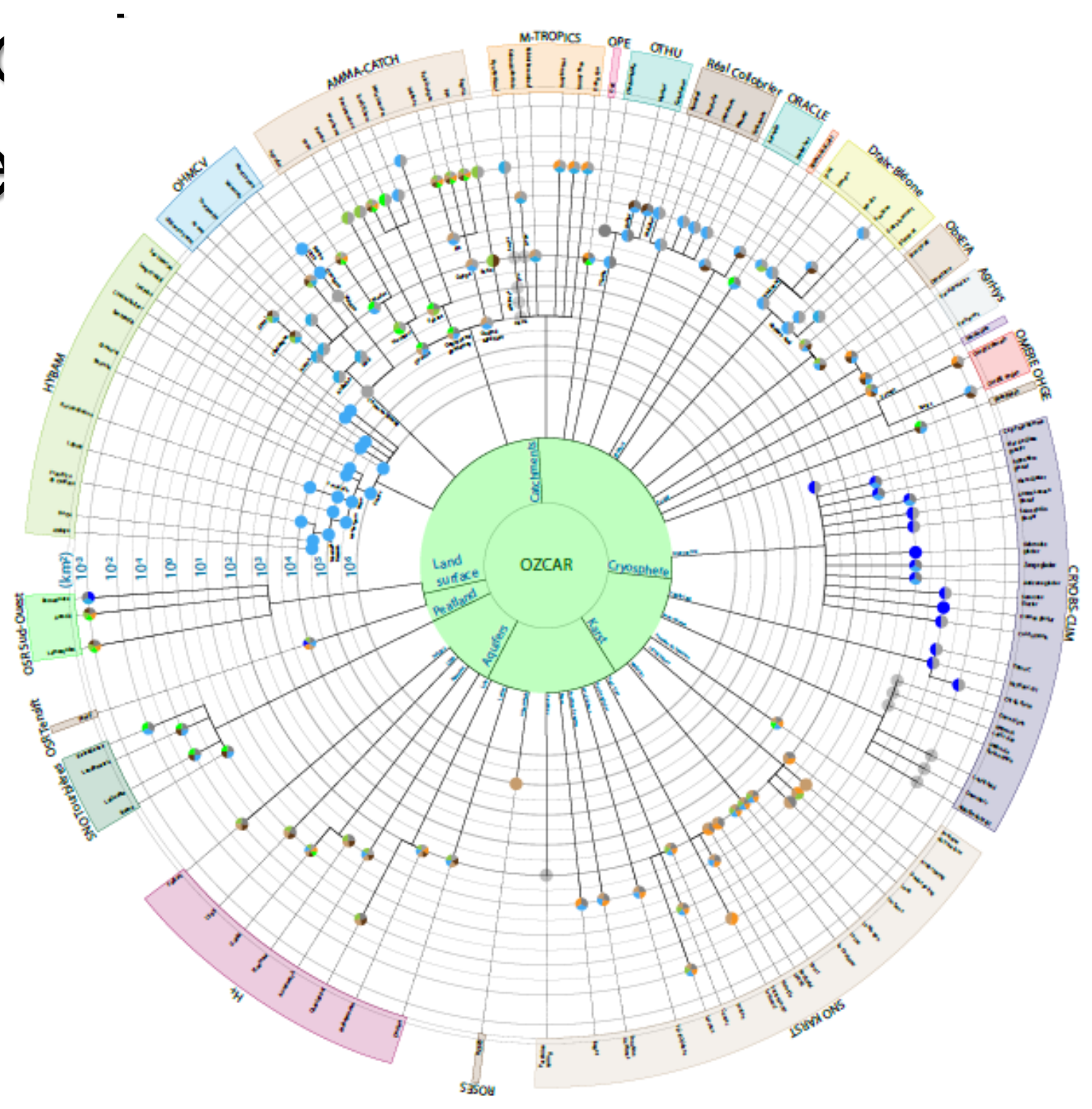




\section{Organization of the tree by objects in the landscape}

- Identification of the objects of interest:

catchments, cryosphere, karst, aquifer, peatland, land surface

$=>$ Reflects the disciplineoriented creation of the observatories

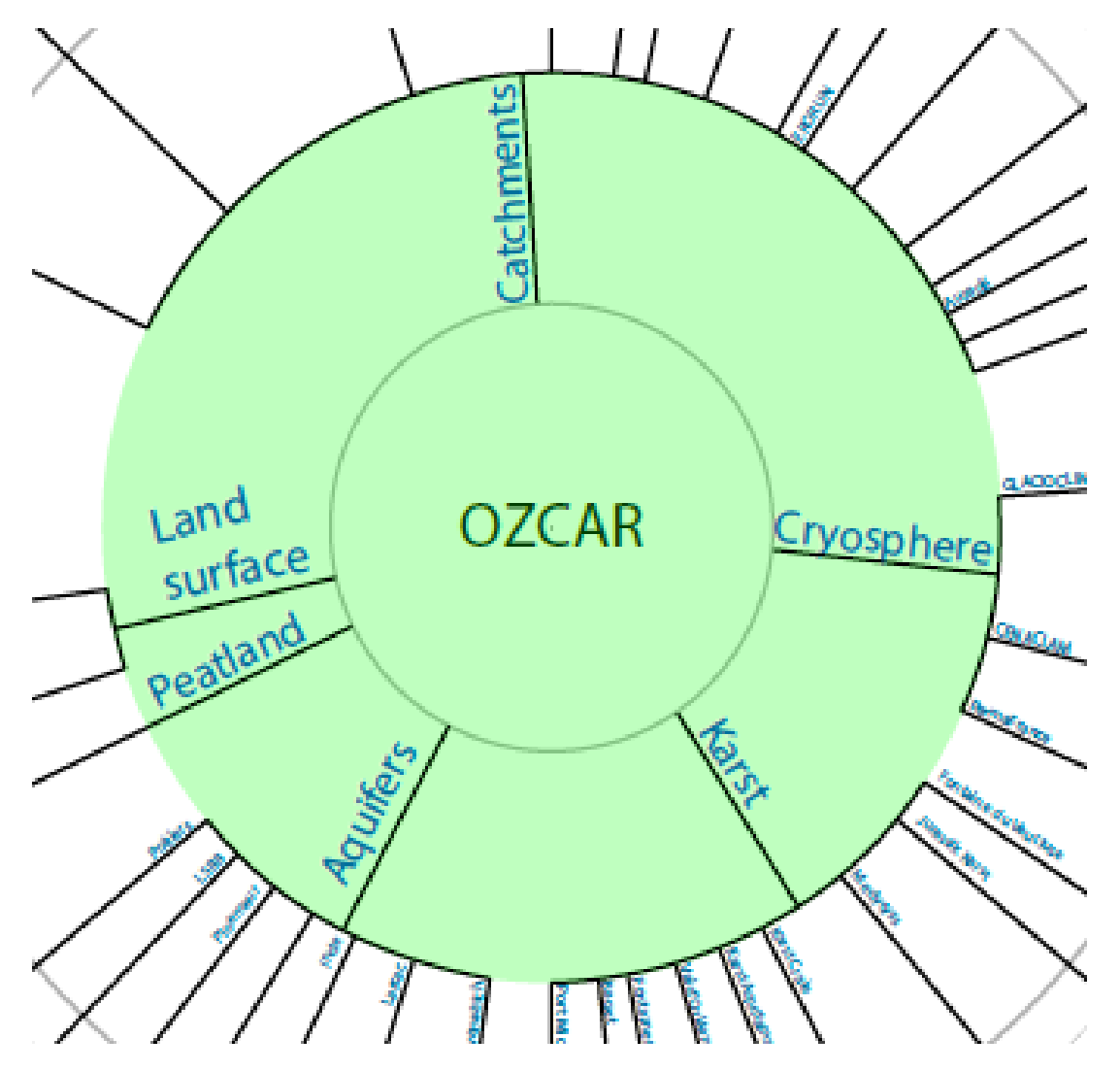




\section{OFAR WERTER}

\section{Main branches represent the}

observatories

- Observatories are labelled entities organized around common scientific questions and generally a common object of interest

$=>$ Reflects the institutional organization of the network (funding, support, human resources)

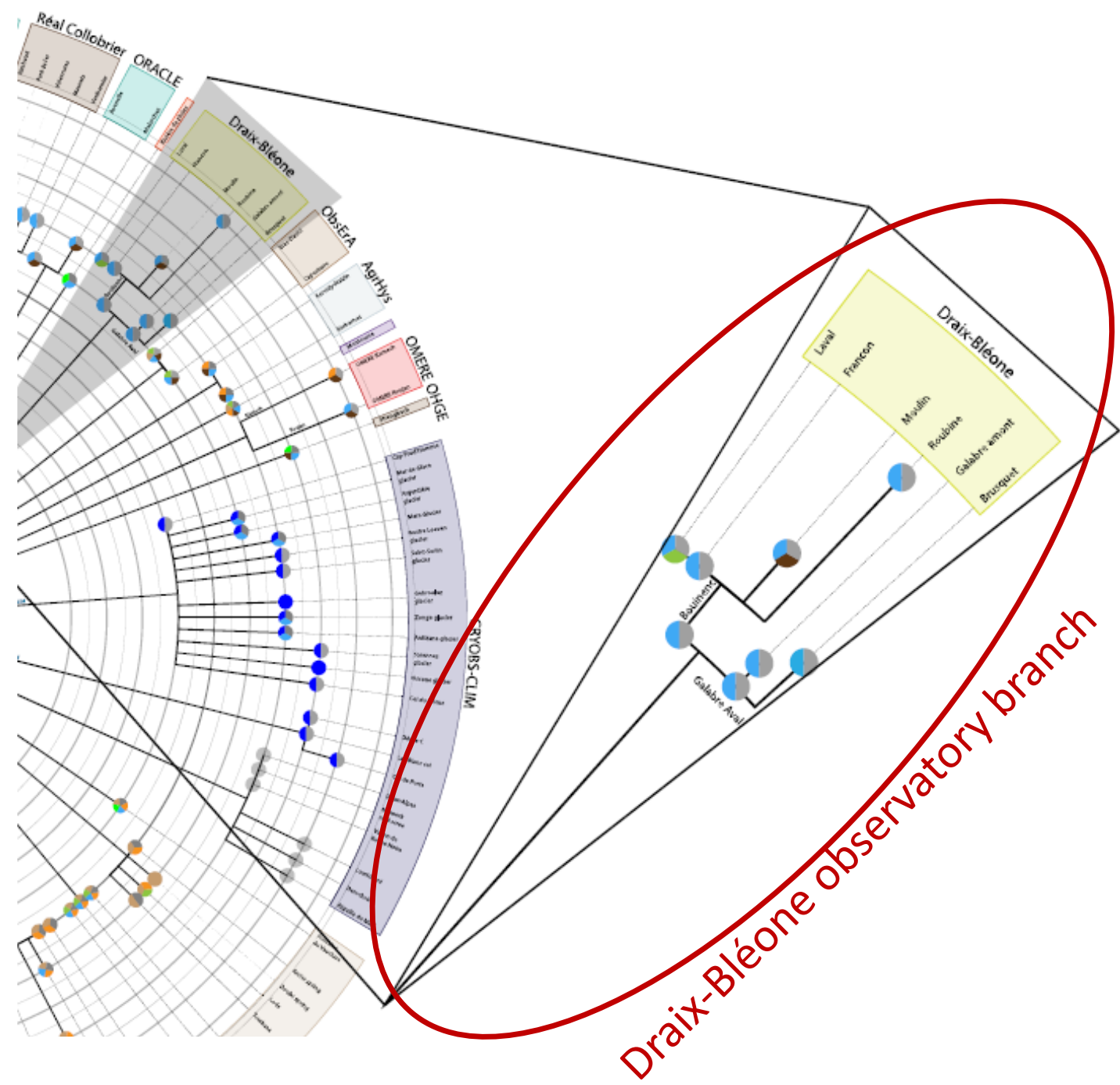




\section{Representation of nested scales of observation}

- The scale of observation is represented by circles: small/plot scales on the larger circle; continental scale close to the center

- The branches represent the nested scales (e.g. nested sub-catchments)

$=>$ Reflects the spatial organization of the network

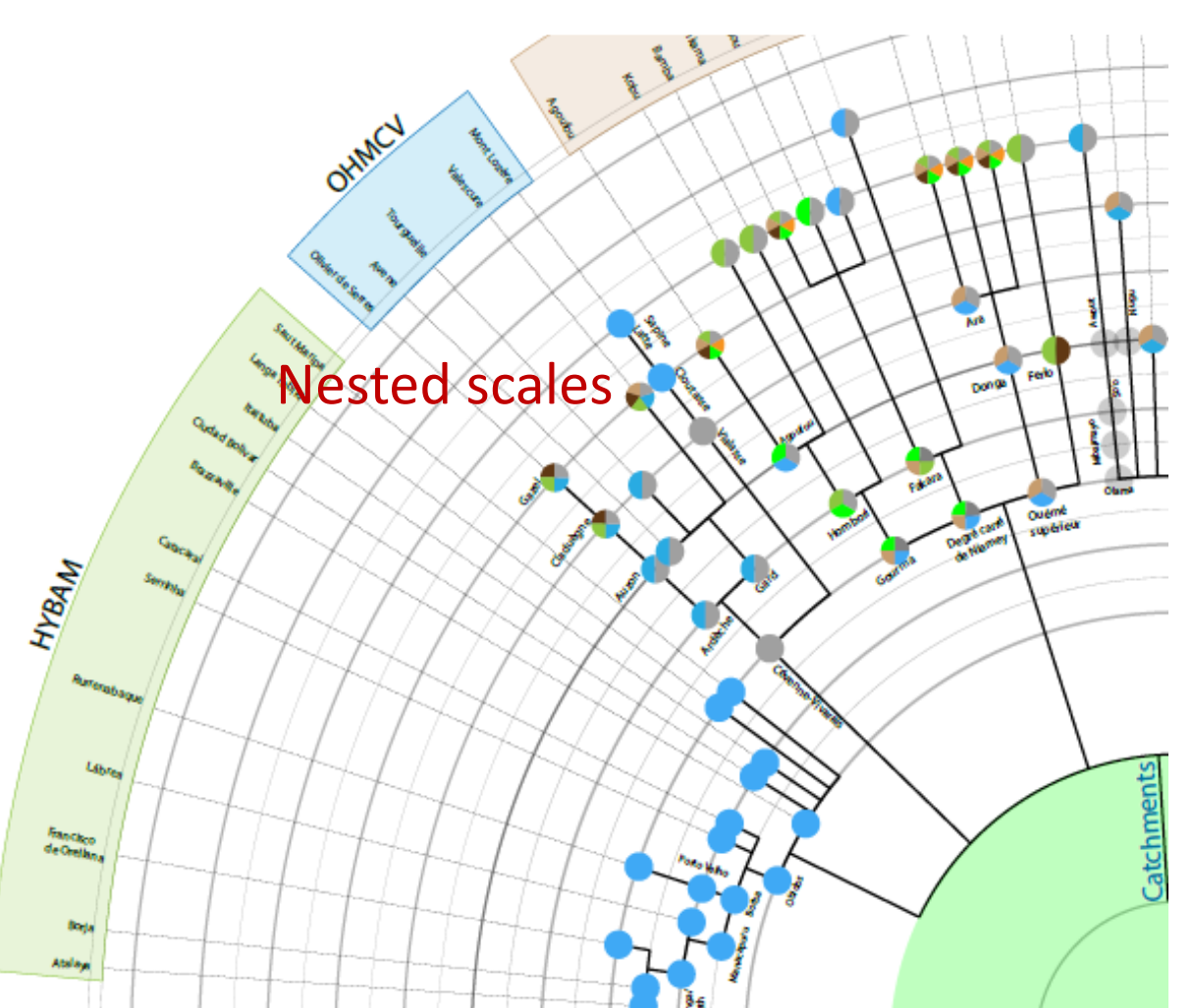

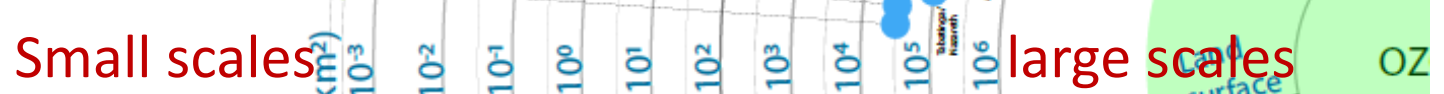

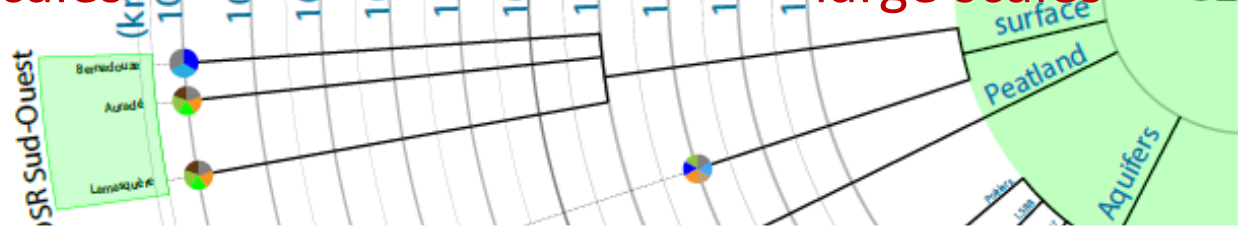




\section{Representation of monitored compartments \\ Small scales}

- The colors in the pies represent the sampled compartments (note that a compartment is listed at one scale if the collected data are representative at this scale)

- In general more compartments are monitored at small scales (process understanding), and are data collected to address change of scales at larger scales

$=>$ Reflects the completeness of the monitoring to address the WAILS

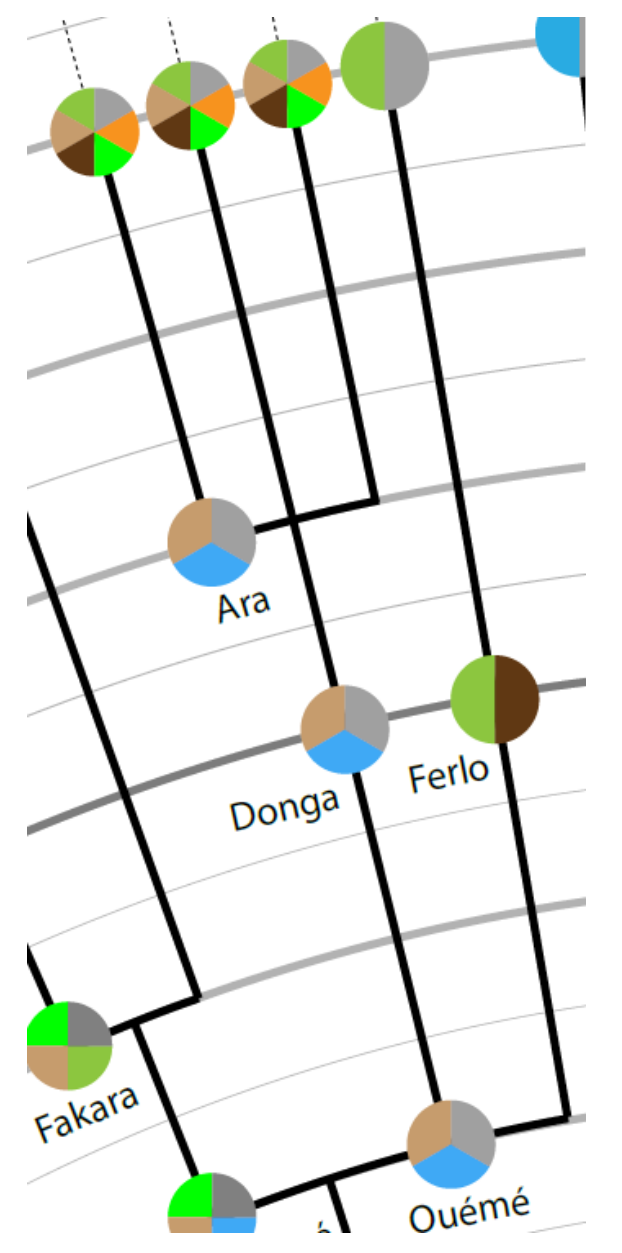

Studied compartments:

Atmosphere

Land use

Biomass

Ice - snow

Soil

Deep water

Surface water

Soil water

large scales 


\section{How to go beyond a nice visualization?}

- A diagnostic tool of existing observation networks

- For OZCAR RI, a network mainly organized around disciplines/objects of interest but also institutional labelling and funding

- The whole network covers most of the compartments identified for the WAILS approach, but none of the sites complies with it

- Help in the identification of the site category:

- Master: the most colored pies

- Focal site: a dominant color in the pie or a single object of interest

- A tool to be complemented with maps to identify colocalized sites with other RIs and build LTSER platforms 
- To go a step further: complement the pies with a visualization of the collected variables and their frequency

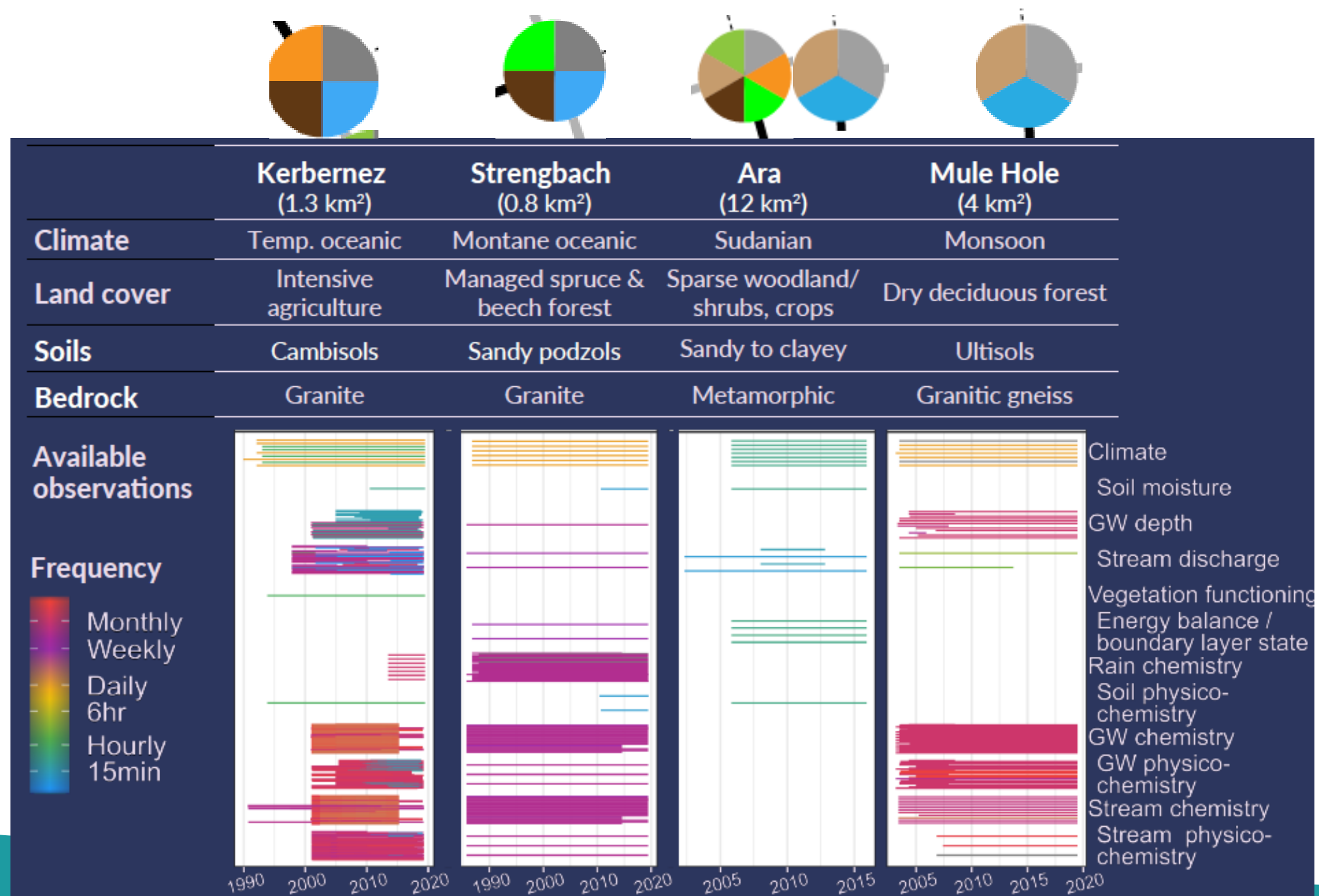

Figure from Kuppel et al., AGU, 2019

BG3.13 - 'Whole system approach for in-situ \& long-term environmental system research on life supporting systems (WAILS) 14 


\section{Conclusions and perspectives}

- First steps towards a tool allowing to summarize the structure and organization of observation networks

- Combined with mapping, a tool that can help identifying and building potential sites category and LTSER platform

- A tool probably needing extensions to be applicable to socioecological networks 


\title{
To learn more about OZCAR RI:
}

Gaillardet, J., Braud, I., Hankard, F., Anquetin, S., Bour, O., Dorfliger, N., de Dreuzy, J.R., Galle, S., Galy, C., Gogo, S., Gourcy, L., Habets, F., Laggoun, F., Longuevergne, L., Le Borgne, T., Naaim-Bouvet, F., Nord, G., Simonneaux, V., Six, D., Tallec, T., Valentin, C., Abril, G., Allemand, P., Arènes, A., Arfib, B., Arnaud, L., Arnaud, N., Arnaud, P., Audry, S., Comte, V.B., Batiot, C., Battais, A., Bellot, H., Bernard, E., Bertrand, C., Bessière, H., Binet, S., Bodin, J., Bodin, X., Boithias, L., Bouchez, J., Boudevillain, B., Moussa, I.B., Branger, F., Braun, J.J., Brunet, P., Caceres, B., Calmels, D., Cappelaere, B., Celle-Jeanton, H., Chabaux, F., Chalikakis, K., Champollion, C., Copard, Y., Cotel, C., Davy, P., Deline, P., Delrieu, G., Demarty, J., Dessert, C., Dumont, M., Emblanch, C., Ezzahar, J., Estèves, M., Favier, V., Faucheux, M., Filizola, N., Flammarion, P., Floury, P., Fovet, O., Fournier, M., Francez, A.J., Gandois, L., Gascuel, C., Gayer, E., Genthon, C., Gérard, M.F., Gilbert, D., Gouttevin, I., Grippa, M., Gruau, G., Jardani, A., Jeanneau, L., Join, J.L., Jourde, H., Karbou, F., Labat, D., Lagadeuc, Y., Lajeunesse, E., Lastennet, R., Lavado, W., Lawin, E., Lebel, T., Le Bouteiller, C., Legout, C., Lejeune, Y., Le Meur, E., Le Moigne, N., Lions, J., Lucas, A., Malet, J.P., Marais-Sicre, C., Maréchal, J.C., Marlin, C., Martin, P., Martins, J., Martinez, J.M., Massei, N., Mauclerc, A., Mazzilli, N., Molénat, J., Moreira-Turcq, P., Mougin, E., Morin, S., Ngoupayou, J.N., Panthou, G., Peugeot, C., Picard, G., Pierret, M.C., Porel, G., Probst, A., Probst, J.L., Rabatel, A., Raclot, D., Ravanel, L., Rejiba, F., René, P., Ribolzi, O., Riotte, J., Rivière, A., Robain, H., Ruiz, L., Sanchez-Perez, J.M., Santini, W., Sauvage, S., Schoeneich, P., Seidel, J.L., Sekhar, M., Sengtaheuanghoung, O., Silvera, N., Steinmann, M., Soruco, A., Tallec, G., Thibert, E., Lao, D.V., Vincent, C., Viville, D., Wagnon, P., Zitouna, R., 2018. OZCAR: The French Network of Critical Zone Observatories. Vadose Zone Journal, 17 (1). https://doi.org/10.2136/vzi2018.04.0067

\section{https://www.ozcar-ri.org/fr/ozcar-observatoires-de-la-zone-critique-applications-et-recherche/}

\section{Contacts:}

\author{
gaillard@ipgp.ir \\ isabelle.braud@inrae.fr \\ Sylvie.galle@ird.fr \\ entringer@ipgp.fr \\ Francois.mercier94@gmail.com
}




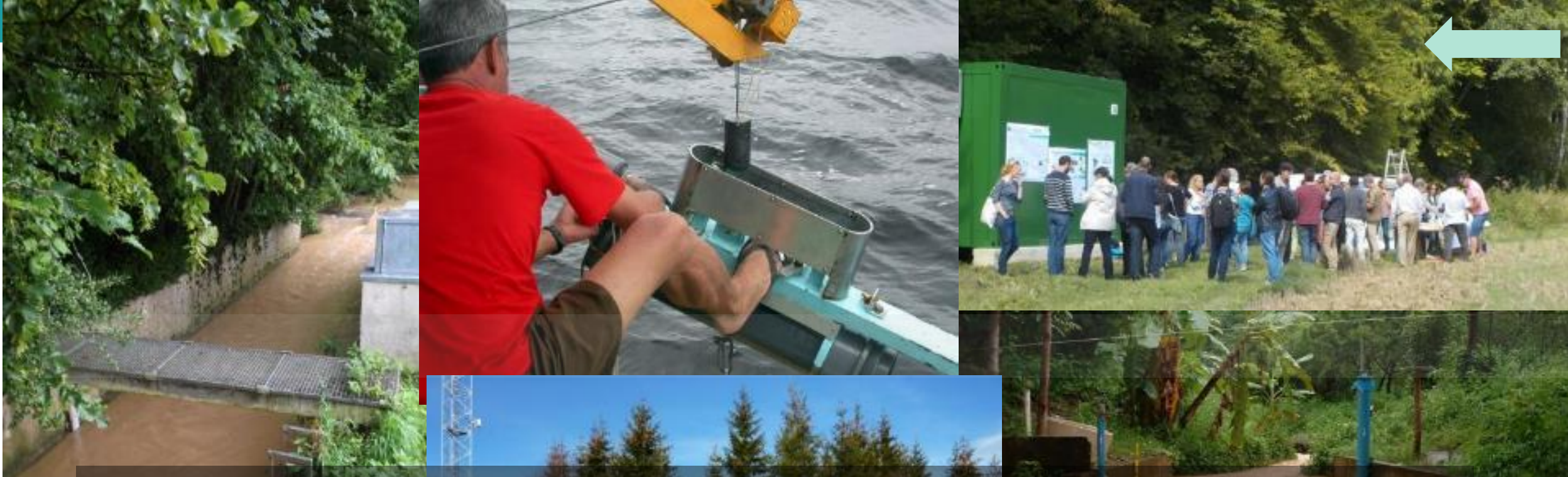

OZCAR and its components are funded by the Ministère de l'Education Nationale et de la Recherche, CNRS, IRD, INRAE, BRGM, ANDRA, Météo-France, and

S.T. Several French universities and foreign institutions

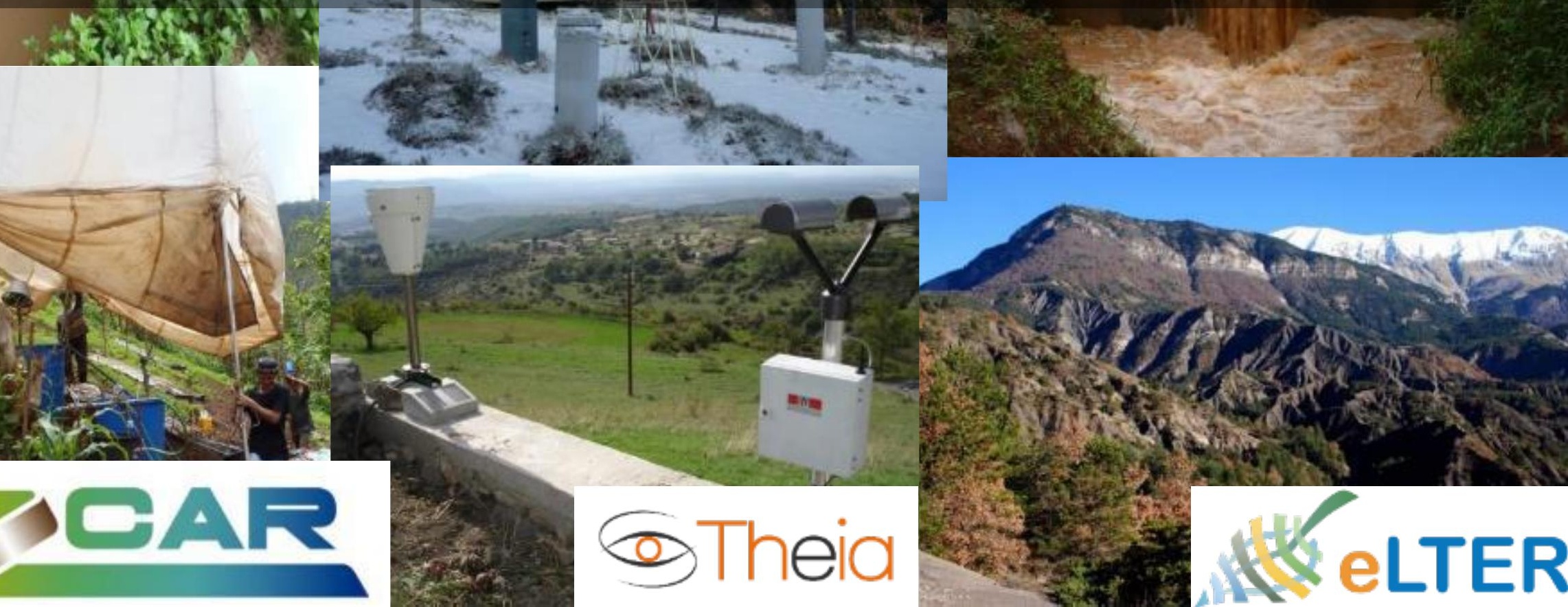

